\title{
The Design of Sensitive, Selective and Reproducible Biosensor With Enzyme Immobilisation For Analytical Applications
}

\author{
Manihar Situmorang ${ }^{*}$, Isnaini Nurwahyuni $^{2}$ \\ \{ msitumorang@unimed.ac.id ${ }^{1}$, isnaininurwahyuni@gmail.com ${ }^{2}$ \}
}

\begin{abstract}
Department of Chemistry, Faculty of Mathematics and Natural Science, Universitas Negeri Medan, J1. Willem Iskandar Psr V Medan, North Sumatera, 20221, INDONESIA, Phone. 062-61-66367571 Department of Biology, Faculty of Mathematics and Natural Science, Universitas Sumatra Utara, Jl. Bioteknologi No 1 Kampus USU Padang Bulan, Medan, North Sumatera, Indonesia $20155^{2}$
\end{abstract}

\begin{abstract}
The design of sensitive, selective and reproducible biosensors with enzyme immobilization for analytical application is reported. The study is aimed to present the design of sensitive, selective and reproducible biosensors with enzyme immobilization to be used as a versatile and accurate analytical tool for the determination of target analytes in real samples. The biosensor device is developed with the employ of the immobilized enzyme as a catalytic agent to convert the target analyte to a product that can be monitored electrochemically. The biosensors, both in amperometric and potentiometric detection system have been reviewed for different types of analytes. A uric acid biosensor is used as a design example. Analytical performances of the uric acid biosensor have been evaluated in terms of the detection sensitivity, linearity detection range, reproducibility, selectivity, and stability. The potential applications of the biosensor design for analytical purposes are also demonstrated.
\end{abstract}

Keywords: Electrochemical biosensor, Reproducible, Enzyme immobilization, Potentiometric, Amperometric, Polytyramine matrix

\section{Introduction}

The search for biosensor designs that have sensitive, selective and high repeatability responses is a challenge in developing biosensors [1]. A biosensor design by integrating biological material with a transducer to produce a measured signal is accounted as a useful analytical tool due to its compact size, real-time analysis, nearly reagentless operation, simple pretreatment protocols and simplicity of use [2]. The designs employ different transduction methods including electrochemical, optical, mass sensitive and calorimetric, where electrochemical measuring principles dominate the biosensor development [3-5]. The combinations of enzymatic reactions with electrochemical transducers have improved the selectivity, sensitivity, and simplicity of measurements [6]. The most common forms of biorecognition used are based on enzymatic catalytic, antibody-antigen interactions, nucleic acid codes, cellular recognitions, and biomimetic materials interactions [7-10]. The transduction for biosensor can be accomplished via optical, mass sensitive, calorimetric, and electrochemical methods, where the electrochemical technique dominated the biosensor field due to its sensitive response and compatible manufacture devices $[11,12]$. The potentiometric method is assigned 
to be very attractive because the instrumentation component is a simple and relatively low-cost instrument compared to another electrochemical detection system [13] and has successfully developed for a number of applications $[14,15]$. The amperometric biosensor has superiority in the detection sensitivity for the measurement of the concentration of analytes [16-19]. The biosensor design has applied for various analytical applications [20,21].

To construct a sensitive enzyme-based biosensor requires the biorecognition molecules to be immobilized to maintain the biological material close to the transducer surface while retaining its catalytic activity [22]. Enzyme based biosensors have utilized enzymes on various types of electrode materials including metals, carbon, organic conducting salts and modified polymers as reviewed in the references [23,24]. Most enzyme electrodes are constructed via entrapment of enzymes throughout polymers [25]. The electrodeposition of the polymer is very interesting in the construction of the biosensors as the technique is able to control the distribution of enzymes without loss of activity and the thickness of the membrane layer [26-28]. Polytyramine with an amine group is an ideal matrix polymer since the interest active biomolecule can be attached to it via covalent linkage $[29,30]$. The enzyme electrodes produced by this system are highly reproducible, have long-term stability, and able to screen interfering species [31].

The uric acid biosensor is a very attractive analytical protocol to discuss since it is known that total uric acid in serum is an indicator of diseases [32-36]. A biosensor with immobilization of enzyme in polytyramine membrane film is used as an example for a sensitive, selective and reproducible biosensor for uric acid assay. The biosensor design is based upon successful development explained previously [37]. The uric acid determination is based on enzymatic catalytic reaction (1) and (2).

$$
\begin{gathered}
\text { Uric acid }+\mathrm{O}_{2}+2 \mathrm{H}_{2} \mathrm{O} \stackrel{\text { vox }}{\longrightarrow} \text { Allantoin }+\mathrm{CO}_{2}+2 \mathrm{H}_{2} \mathrm{O}_{2} \\
\mathrm{H}_{2} \mathrm{O}_{2} \stackrel{\text { GC/Pt }}{\longrightarrow} 2 \mathrm{H}^{+}+\mathrm{O}_{2}+2 \mathrm{e}^{-}
\end{gathered}
$$

Sample of uric acid is oxidize become allantoin and the hydrogen peroxide by the catalytic reaction made by uric oxidase (UOx). The released $\mathrm{H}_{2} \mathrm{O}_{2}$ is detected amperometrically and the current obtained is equivalent to the amount of the uric acid in the sample. The study is aimed to present the design of sensitive, selective and reproducible biosensors with enzyme immobilization to be used as a versatile and accurate analytical tool for the determination of uric acid in real samples. The approaches are explaining the production of an enzyme electrode via immobilization of uric oxidase through polytyramine membrane film, with special regard to the construction of reproducible, sensitive and selective response to a target analyte with long term stability for repetitive usage.

\section{Experimental}

\subsection{Reagents}

Analytical grade of tyramine (4-hydroxyphenethylamine), uric acid, Uric acid oxidase (UOx) 50 unit/mg (E.C 1.7.3.3), peroxidase (POx) 179 units/mg (E.C.1.11.1.7.2) from horseradish, 1-ethyl-3(3 dimethylaminopropyl) carbodiimide hydrochloride (EDC), and Nhydroxysuccinimide (NHS) were purchased from Sigma Chem. Co. Other chemicals such as hexachloroplatinate(IV) and $\mathrm{Li}_{2} \mathrm{CO}_{3}$ were obtained from Aldrich Chem. Co. The reagents were dissolved in deionized water. 


\subsection{Instrumentation}

The instruments used are consisted of a BAS 100B (Bioanalytical System Inc. Lafayette) potentiostat, a glassy carbon disk electrode (area $0.070 \mathrm{~cm}^{2}$ ) as working electrode (BAS), an $\mathrm{Ag} / \mathrm{AgCl}$ the reference electrode $(\mathrm{BAS})$ and a homemade platinum wire electrode $(1 \mathrm{~cm}, 0.5$ $\mathrm{mm}$ diameter) as the auxiliary electrode.

\subsection{Procedures}

An enzyme electrode used in the uric acid biosensor is constructed via the immobilization of uric oxidase (UOx) in polytyramine matrix polymer. The detail explanation for the preparation of uric acid biosensor is available in Indonesian patent [38]. Briefly, the enzyme electrode was prepared to start from the electrodeposition of platinum on to the surface of glassy carbon (GC) to obtain a platinized glassy carbon electrode $(\mathrm{GC} / \mathrm{Pt})$. The enzyme uric acid oxidase is then immobilized onto the GC/Pt electrode by the use of electrodeposited polytyramine matrix, followed by coupling with EDC and NHS to produce an enzyme electrode (GC/Pt/Pty/UOx). The developed electrode is stored dry overnight at $4{ }^{\circ} \mathrm{C}$ and was soaked in a buffer solution ( $\mathrm{pH}$ 6.0) for five minutes for conditioning before use. The enzyme electrode $(\mathrm{GC} / \mathrm{Pt} / \mathrm{Pty} / \mathrm{UOx}$ vs $\mathrm{Ag} / \mathrm{AgCl})$ is then interfaced with a potentiostat for current measurements. The uric acid standard solution and the sample is dissolved in $4 \%$ lithium carbonate solution to allow the uric acid dissolved in aqueous solution. The determination of uric acid proceeds at optimum experimental conditions $[37,38]$.

\section{Results and Discussion}

\subsection{Membran Film With Immobilised Enzyme}

Polytyramine membrane film with immobilized UOx has been prepared electrochemically from aqueous tyramine solution containing enzyme by using cyclic voltammetry (CV) for five sweep cycles (Figure 1). Thin membrane film was strongly attached to the GC/Pt electrode. The surface of the GC/Pt electrode was blocked by the film with the attached enzyme throughout the polytyramine membrane (GC/Pt/Pty/UOx) [31].

Immobilization of the enzyme onto the electrode surface during the electropolymerization process is a one-step procedure in obtaining reproducible biosensors [39]. The enzyme is entrapped throughout polytyramine membrane films followed by covalent attachment similar to other biosensors [40-42]. Covalent bonding between the enzymes with the polytyramine is achieved by exploiting the amine group through the carbodiimide linkage [39]. The immobilized enzyme provides a stable linkage to the matrix polymer and closely attached to the electrode surface [43]. This generic method overcomes the problem of the stability of the biorecognition materials that are commonly found in a biosensor. The design of the biosensor is illustrated in Figure 2 . 


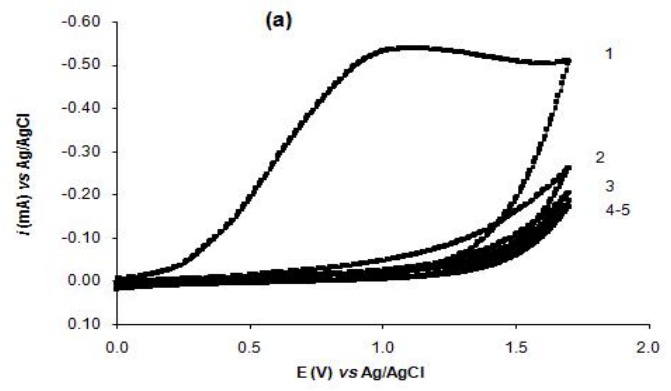

(b)

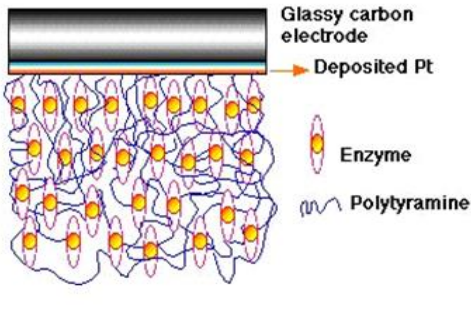

Fig. 1. Preparation of enzyme electrode GC/Pt/Pty/UOx: (a) Electropolymerization of tyramine (CV at 0.01-1.6 V vs Ag/AgCl, scan rate $0.5 \mathrm{~V} \mathrm{~s}^{-1} v s \mathrm{Ag} / \mathrm{AgCl}$ ) for five sweep cycles in solution of $0.05 \mathrm{M}$ phosphate buffer, pH 6.0 containing 0.1 M tyramine and enzyme uric oxidase; (b) Enzyme UOx immobilized on the surface of GC/Pt electrode entrapped by polytyramine matrix.

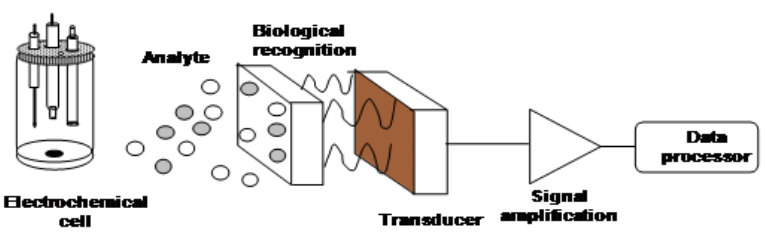

Fig. 2. General design features the biorecognition, transducer and electronic device in a typical biosensor.

\subsection{Biosensor Response Curves}

Typical of biosensor signal response for determination of uric acid is shown in Figure 3a, which is currents from the oxidation of $\mathrm{H}_{2} \mathrm{O}_{2}$ produced in the catalytic reaction of uric acid. The current increased linearly as increasing the concentration of uric acid in the bulk solution. The response signal to uric acid is very fast, it takes only 30 seconds from the injection of the samples until the current increased, and the time needed to obtain a steady-state current proceeded about two minutes. The addition of a higher concentration of the uric acid standard solution is then be made after achieving steady-state current until a series concentration of uric acid standard solutions has been analyzed. The calibration curve for the successive current of standard uric acid was presented in Figure 3b. The detection linearity of the biosensor is obtained in the range concentration of $0.05-0.3 \mathrm{mM}$ uric acid. The calibration slope was $0.0661 \mu \mathrm{A} \mathrm{mM} \mathrm{m}^{-1}$, limit detection is $0.001 \mathrm{mM}$ uric acid where the signal to noise ratio is three $(\mathrm{S} / \mathrm{N}=3)$. This typical wide linearity detection range has been adequate to be applied for the determination of uric acid in real samples without pretreatment, except the dilution with lithium carbonate for very concentrated samples, as well as dissolving the uric acid in aqueous solution [37]. 

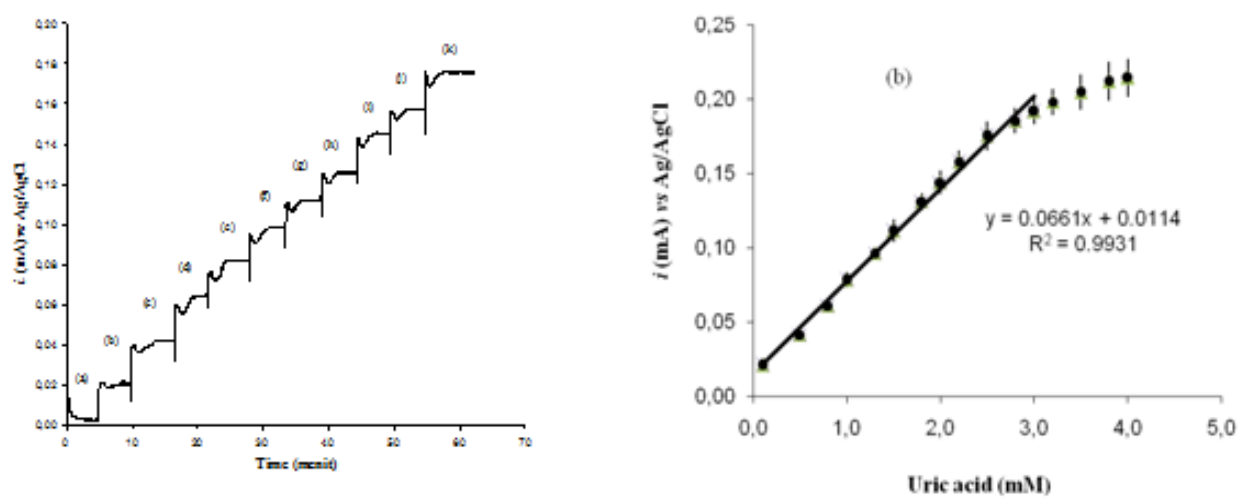

Fig. 3. (a) A steady-state current response for uric acid standard solution: a-k represents the successive injection of $0.1-2.5 \mathrm{mM}$ uric acid into phosphate buffer solution ( $0.05 \mathrm{M}, \mathrm{pH} 6.0)$ containing $4 \%$

$\mathrm{Li}_{2} \mathrm{CO}_{3}$. (b) Calibration curves of the uric acid standard solution obtained from five enzyme electrodes that were prepared at different days with a similar method. The experimental parameter in the preparation of an enzyme electrode is in Figure 1.

The calibration plot presented in Figure 2b is the result of multiple measurements of standards uric acid solutions from five enzyme electrodes. The electrodes are made at different times from different batches of solutions with similar experimental preparation methods. The reproducibility of the biosensor is very good, where relative standard deviation (RSD) obtained for low concentration of uric acid is less than $1 \%$ and for a high concentration of uric acid is less than $6 \%$. The biosensor also demonstrated to have good stability when used for repetitive measurements for uric acid samples. The good performance of the biosensor was achieved as a result of suit combinations between the biological components and the transducers in the detection system. The polytyramiene maintains stable in the activity of the enzyme and facilitate the protection of enzyme from denaturation and fouling.

The accuracy of uric acid biosensor has been demonstrated by determining the amount of uric acid in standard control solutions and serum samples. The results given by the biosensor are compared to the assigned values of uric acid in reference control solutions (Accutrol Normal and abnormal, Sigma Co.). Measurements are also been done for uric acid in serum samples (Blood serum 1-6, hospital). The amounts of uric acid obtained by the biosensor are identic to the value of reference control solutions and sera samples (Table 1). A plot of these results between the biosensor against the standard method gave a correlation coefficient of 0.966 . The results confirmed that the uric acid biosensor has high accuracy, and the recovery obtained by the biosensor meets the expected value for uric acid in reference control samples (see Table 1).

The selectivity of uric acid biosensor has also been evaluated by analyzing the standard uric acid samples in the presence of a high concentration of common suspected interfering agents in the clinical samples. The high concentration of interfering agents did not influence the response signal for uric acid [45]. The study has proven that uric acid biosensor was free from interferences. The biosensor designed has successfully been applied for the construction of other biosensors for various types of analytes, both in amperometric and potentiometric detection methods [46,47]. The model biosensor has fulfilled the rigid demand for the construction of versatile biosensor. 
Table 1. The analysis of uric acid in reference standard samples by two methods, the uric acid biosensor, and the standard spectrophotometric method. The values are the averages from three measurements.

\begin{tabular}{|c|c|c|c|}
\hline \multirow{2}{*}{$\begin{array}{l}\text { Reference } 0073 \text { tandard and Blood } \\
\text { Serum Samples containing Uric acid }\end{array}$} & \multicolumn{2}{|c|}{ Uric acid $(\mathrm{mM})$} & \multirow[b]{2}{*}{ Recovery } \\
\hline & $\begin{array}{l}\text { Spectrophotometric } \\
\text { method }^{*}\end{array}$ & Biosensor $^{* *}$ & \\
\hline Accutrol Normal (Sigma Co.) & 0.0313 & 0.0333 & 106 \\
\hline Accutrol Elevated (Sigma Co.) & 0.0483 & 0.0511 & 106 \\
\hline Blood serum 1 & 0.0262 & 0.0296 & 113 \\
\hline Blood serum 2 & 0.0291 & 0.0301 & 103 \\
\hline Blood serum 3 & 0.0331 & 0.0339 & 102 \\
\hline Blood serum 4 & 0.0342 & 0.0341 & 100 \\
\hline Blood serum 5 & 0.0344 & 0.0351 & 102 \\
\hline Blood serum 6 & 0.0351 & 0.0355 & 101 \\
\hline
\end{tabular}

${ }^{*}$ Standard method of spectrophotometry was carried out at $\lambda 520 \mathrm{~nm}$ by using an $o$-dianisidine absorbing agent

${ }^{* *}$ The biosensor measurements were conducted by using enzyme electrode $\mathrm{GC} / \mathrm{Pt} / \mathrm{Pty} / \mathrm{UOx}(\mathrm{E}=0.60 \mathrm{mV} v \mathrm{~s} \mathrm{Ag} / \mathrm{AgCl})$

\section{Conclusion}

Biosensor design with immobilization of enzymes onto the surface of the electrode has been developed. The performance of the biosensor is excellent in terms of sensitivity, selectivity, and reproducibility of measurements to target analyte. The biosensor constructed by using electrodeposited polymer is easy to construct, simple in the preparation technique and has superior in long-term usage stability. The deposited polytyramine matrix polymer is able to maintain enzyme activity, has the ability to prevent the enzyme from denaturation and fouling, and able to exclude interfering species pass into the electrode. The uric acid biosensor presented in this study provided accurate measurements and free from interference.

\section{Acknowledgments}

The author acknowledged the research grant given by the Directorate of Research and Community Service, Directorate General of Research and Development Strengthening, Ministry of Research, Technology and the Higher Education Republic of Indonesia, Financial Year 2019, Under Penelitian Tesis Magister, Contract No.0031/UN33.8/PL-DRPM/2019.

\section{References}

[1] Juan-Colás, J., Johnson, S., \& Krauss, T. F.: Dual-Mode Electro-Optical Techniques for Biosensing Applications: A Review. Sensors (Basel, Switzerland), 17(9), 2047. doi:10.3390/s17092047 (2017) [2] Chorsi, H. T., Zhu, Y., \& Zhang, J.: Patterned Plasmonic Surfaces-Theory, Fabrication, and Applications in Biosensing. Journal of microelectromechanical systems : a joint IEEE and ASME 
publication on microstructures, microactuators, microsensors, and microsystems, 26(4), 718-739. doi:10.1109/JMEMS.2017.2699864 (2017)

[3] Justino, C., Duarte, A. C., \& Rocha-Santos, T.: Recent Progress in Biosensors for Environmental Monitoring: A Review. Sensors (Basel, Switzerland), 17(12), 2918. doi:10.3390/s17122918 (2017)

[4] Geng, Z., Zhang, X., Fan, Z., Lv, X., Su, Y., \& Chen, H.: Recent Progress in Optical Biosensors Based on Smartphone Platforms. Sensors (Basel, Switzerland), 17(11), 2449. doi:10.3390/s17112449 (2017)

[5] Sharma, D., Lee, J., Seo, J., \& Shin, H.: Development of a Sensitive Electrochemical Enzymatic Reaction-Based Cholesterol Biosensor Using Nano-Sized Carbon Interdigitated Electrodes Decorated with Gold Nanoparticles. Sensors (Basel, Switzerland), 17(9), 2128. doi:10.3390/s17092128 (2017)

[6] Asal, M., Özen, Ö., Şahinler, M., \& Polatoğlu, İ.: Recent Developments in Enzyme, DNA and Immuno-Based Biosensors. Sensors (Basel, Switzerland), 18(6), 1924. doi:10.3390/s18061924 (2018) [7] Nguyen, H. H., Lee, S. H., Lee, U. J., Fermin, C. D., \& Kim, M.: Immobilized Enzymes in Biosensor Applications. Materials (Basel, Switzerland), 12(1), 121. doi:10.3390/ma12010121 (2019)

[8] Zhou, L., He, X., He, D., Wang, K., \& Qin, D.: Biosensing technologies for Mycobacterium tuberculosis detection: status and new developments. Clinical \& developmental immunology, 2011, 193963. doi:10.1155/2011/193963 (2011)

[9] Zhou, L., He, X., He, D., Wang, K., \& Qin, D.: Biosensing technologies for Mycobacterium tuberculosis detection: status and new developments. Clinical \& developmental immunology, 2011, 193963. doi:10.1155/2011/193963 (2011)

[10] Prada, J., Cordes, C., Harms, C., \& Lang, W.: Design and Manufacturing of a Disposable, CycloOlefin Copolymer, Microfluidic Device for a Biosensor $\uparrow$. Sensors (Basel, Switzerland), 19(5), 1178. doi:10.3390/s19051178783 (2019)

[11] Hasan, A., Nurunnabi, M., Morshed, M., Paul, A., Polini, A., Kuila, T., Al Hariri, M., Lee, Y.K., \& Jaffa, A. A.: Recent advances in application of biosensors in tissue engineering. BioMed research international, 2014, 307519. doi:10.1155/2014/307519 (2014)

[12] Neethirajan, S., Ragavan, V., Weng, X., \& Chand, R.: Biosensors for Sustainable Food Engineering: Challenges and Perspectives. Biosensors, 8(1), 23. doi:10.3390/bios8010023(2018)

[13] Saeedfar, K., Heng, L. Y., Ling, T. L., \& Rezayi, M. (2013). Potentiometric urea biosensor based on an immobilised fullerene-urease bio-conjugate. Sensors (Basel, Switzerland), 13(12), 16851-16866. doi:10.3390/s131216851 (2013)

[14] Cuartero, M., Parrilla, M., \& Crespo, G. A.: Wearable Potentiometric Sensors for Medical Applications. Sensors (Basel, Switzerland), 19(2), 363. doi:10.3390/s19020363 (2019)

[15] Situmorang, M., Gooding, J.J., Hibbert, D.B. and Barnett, D.: Development of potentiometric biosensors using electrodeposited polytyramine as the enzyme immobilisation matrix. Electroanalysis, 13(18): 1469-1474 (2001)

[16] Apetrei, I. M., \& Apetrei, C.:. Amperometric Biosensor Based on Diamine Oxidase/Platinum Nanoparticles/Graphene/Chitosan Modified Screen-Printed Carbon Electrode for Histamine Detection. Sensors (Basel, Switzerland), 16(4), 422. doi:10.3390/s16040422 (2016)

[17] Nik Mansor, N. N., Leong, T. T., Safitri, E., Futra, D., Ahmad, N. S., Nasuruddin, D. N., Itnin, A., Zaini, I. Z., Arifin, K. T., Heng, L. Y., \& Hassan, N. I.: An Amperometric Biosensor for the Determination of Bacterial Sepsis Biomarker, Secretory Phospholipase Group 2-IIA Using a TriEnzyme System. Sensors (Basel, Switzerland), 18(3), 686. doi:10.3390/s18030686 (2018)

[18] Artigues, M., Abellà, J., \& Colominas, S.: Analytical Parameters of an Amperometric Glucose Biosensor for Fast Analysis in Food Samples. Sensors (Basel, Switzerland), 17(11), 2620. doi:10.3390/s17112620 (2017)

[19] Mungroo, N. A., \& Neethirajan, S.: Biosensors for the detection of antibiotics in poultry industrya review. Biosensors, 4(4), 472-493. doi:10.3390/bios4040472 (2014)

[20] Zhao, Z., Lei, W., Zhang, X., Wang, B., \& Jiang, H.: ZnO-based amperometric enzyme biosensors. Sensors (Basel, Switzerland), 10(2), 1216-1231. doi:10.3390/s100201216 (2010)

[21] El Harrad, L., Bourais, I., Mohammadi, H., \& Amine, A.: Recent Advances in Electrochemical Biosensors Based on Enzyme Inhibition for Clinical and Pharmaceutical Applications. Sensors (Basel, Switzerland), 18(1), 164. doi:10.3390/s18010164 (2018) 
[22] Ayranci, R., Demirkol, D. O., Ak, M., \& Timur, S.: Ferrocene-functionalized 4-(2,5-Di(thiophen2-yl)-1H-pyrrol-1-yl)aniline: a novel design in conducting polymer-based electrochemical biosensors. Sensors (Basel, Switzerland), 15(1), 1389-1403. doi:10.3390/s150101389 (2015)

[23] Carrasco S.: Metal-Organic Frameworks for the Development of Biosensors: A Current Overview. Biosensors, 8(4), 92. doi:10.3390/bios8040092. (2018)

[24] Tomczykowa, M., \& Plonska-Brzezinska, M. E.: Conducting Polymers, Hydrogels and Their Composites: Preparation, Properties and Bioapplications. Polymers, 11(2), 350. doi:10.3390/polym11020350 (2019)

[25] Idrissi, M. E., Meyer, C. E., Zartner, L., \& Meier, W.: Nanosensors based on polymer vesicles and planar membranes: a short review. Journal of nanobiotechnology, 16(1), 63. doi:10.1186/s12951018-0393-7 (2018)

[26] Zhao, Y., Cao, L., Li, L., Cheng, W., Xu, L., Ping, X., Pan, L., \& Shi, Y.: Conducting Polymers and Their Applications in Diabetes Management. Sensors (Basel, Switzerland), 16(11), 1787. doi:10.3390/s16111787 (2016)

[27] Mancuso, M., Goddard, J. M., \& Erickson, D:. Nanoporous polymer ring resonators for biosensing. Optics express, 20(1), 245-255. doi:10.1364/OE.20.000245 (2012)

[28] Faridbod, F., Norouzi, P., Dinarvand, R., \& Ganjali, M. R.: Developments in the Field of Conducting and Non-conducting Polymer Based Potentiometric Membrane Sensors for Ions Over the Past Decade. Sensors (Basel, Switzerland), 8(4), 2331-2412. doi:10.3390/s8042331 (2008)

[29] Lai, C. K., Foot, P. J., Brown, J. W., \& Spearman, P.: A Urea Potentiometric Biosensor Based on a Thiophene Copolymer. Biosensors, 7(1), 13. doi:10.3390/bios7010013 (2017)

[30] Ulianas, A., Heng, L. Y., \& Ahmad, M.: A biosensor for urea from succinimide-modified acrylic microspheres based on reflectance transduction. Sensors (Basel, Switzerland), 11(9), 8323-8338. doi:10.3390/s110908323 (2011)

[31] Situmorang, M.; Gooding, J.J.; Hibbert, D.B. dan Barnett, D.: Electrodeposited Polytyramine as an Immobilisation Matrix for Enzyme Biosensors, Biosensors \& Bioelectronics 13(9), 953-962 (1998)

[32] Kang, D. H., \& Nakagawa, T.: Uric acid and chronic renal disease: possible implication of hyperuricemia on progression of renal disease, Semin Nephrol 25(1): $43-49$ (2005)

[33] Jin, M., Yang, F., Yang, I., Yin, Y., Luo, J.J., Wang, H., and Yang, X.F.: Uric acid, hyperuricemia and vascular diseases, Front Biosci. 17: 656-669 (2012)

[34] Kim, J., Imani, S., de Araujo, W. R., Warchall, J., Valdés-Ramírez, G., Paixão, T. R., Mercier, P. P., \& Wang, J.: Wearable salivary uric acid mouthguard biosensor with integrated wireless electronics. Biosensors \& bioelectronics, 74, 1061-1068. doi:10.1016/j.bios.2015.07.039 (2015)

[35] Ibupoto, Z. H., Tahira, A., Raza, H., Ali, G., Khand, A. A., Jilani, N. S., Mallah, A. B., Yu, C., \& Willander, M.: Synthesis of Heart/Dumbbell-Like CuO Functional Nanostructures for the Development of Uric Acid Biosensor. Materials (Basel, Switzerland), 11(8), 1378. doi:10.3390/ma11081378 (2018) [36] Lee, H. C., Zhang, L. F., Lin, J. L., Chin, Y. L., \& Sun, T. P.: Development of anodic titania nanotubes for application in high sensitivity amperometric glucose and uric acid biosensors. Sensors (Basel, Switzerland), 13(10), 14161-14174. doi:10.3390/s131014161 (2013)

[37] Situmorang, M. and Nurwahyuni, I.: The Development of Reproducible and Selective Uric Acid Biosensor by Using Electrodeposited Polytyramine as Matrix Polymer. Indones. J. Chem., 17(3): 461470 (2017)

[38] Situmorang, M., and Nurwahyuni, I.: Biosensor Elektrokimia Untuk Penentuan Asam Urat, Indonesian Patent No. IDP000051693, 09 July 2018 (2019).

[39] Situmorang, M., Gooding, J.J., \& Hibbert, D.B.,: Immobilisation of Enzyme Throughout a Polytyramine Matrix: A Versatile Procedure for Fabricating Biosensors, Analytica Chimica Acta 394(23): 211-223 (1999)

[40] Rocchitta, G., Spanu, A., Babudieri, S., Latte, G., Madeddu, G., Galleri, G., Nuvoli, S., Bagella, P., Demartis, M.I., Fiore, V., Manetti, R., \& Serra, P. A.: Enzyme Biosensors for Biomedical Applications: Strategies for Safeguarding Analytical Performances in Biological Fluids. Sensors (Basel, Switzerland), 16(6), 780. doi:10.3390/s16060780 (2016)

[41] Crapnell, R. D., Hudson, A., Foster, C. W., Eersels, K., Grinsven, B. V., Cleij, T. J., Banks, C.E., \& Peeters, M.: Recent Advances in Electrosynthesized Molecularly Imprinted Polymer Sensing 
Platforms for Bioanalyte Detection. Sensors (Basel, Switzerland), 19(5), 1204. doi:10.3390/s19051204 (2019)

[42] Luka, G., Ahmadi, A., Najjaran, H., Alocilja, E., DeRosa, M., Wolthers, K., Malki, A., Aziz, H., Althani, A., \& Hoorfar, M.: Microfluidics Integrated Biosensors: A Leading Technology towards Labon-a-Chip and Sensing Applications. Sensors (Basel, Switzerland), 15(12), 30011-30031. doi:10.3390/s151229783 (2015)

[43] Ford, R., Quinn, S. J., \& O'Neill, R. D.: Characterization of Biosensors Based on Recombinant Glutamate Oxidase: Comparison of Crosslinking Agents in Terms of Enzyme Loading and Efficiency Parameters. Sensors (Basel, Switzerland), 16(10), 1565. doi:10.3390/s16101565 (2016)

[44] Sihombing, K., Tamba, M.C., Marbun, W.S. \& Situmorang, M.: Urease immobilized potentiometric biosensor for determination of urea. Indian Journal of Chemistry, 57A(2): 175-180 (2018)

[45] Situmorang, M., Hibbert, D. B., \& Gooding, J. J.: An experimental design study of interferences of clinical relevance of a polytyramine immobilized-enzyme biosensor, Electroanalysis 12 (2), 111119 (2000)

[46] Situmorang, M., Gooding, J. J., Hibbert, D. B. \& Barnett, D.: The Development of a Pyruvate Biosensor Using Electrodeposited Polytyramine, Electroanalysis 14(1), (2002): 17-21., ISSN 10400397 (2002)

[47] Situmorang, M., Hibbert, D.B., Gooding, J.J., and Barnett, D.: A Sulfite Biosensor Fabricated Using Electrodeposited Polytyramine: Application to Wine Analysis, Analyst 124(12): 1775-1779 (1999) 